\title{
Grain Quality Evaluation and Organoleptic Analysis of Aromatic Rice Varieties of Goa, India
}

\author{
Shilpa J. Bhonsle \\ Department of Botany, Goa University \\ Goa-403 206, India \\ Tel: 91-904-980-0956 E-mail: shilpa_24june@yahoo.co.in \\ Sellappan Krishnan (Corresponding author) \\ Department of Botany, Goa University \\ Goa-403 206, India \\ Tel: 91-832-651-9348_E-mail: skrish8@yahoo.com
}

The authors acknowledge the financial support provided by the Department of Science, Technology \& Environment, Goa, India and University Grants Commission (UGC), New Delhi, India under SAP (Special Assistance Programme) to carry out this research work.

\begin{abstract}
Rice grain quality characteristics such as physical (hulling, length and breadth (L/B), grain classification, chalkiness, chalk index), chemical (alkali spreading value (ASV), amylose content (AC), gel consistency (GC), aroma), cooking (volume expansion, elongation ratio (ER), water uptake) and organoleptic-tests based on consumer preferences like appearance, cohesiveness, tenderness on touching, chewing, taste, aroma, elongation and overall acceptability were studied for fourteen aromatic rice varieties. The higher hulling percentage was recorded in 'Ek-Kadi' (82.46\%) and 'Ghansal' (80.96\%). The Length/Breadth (L/B) ratio among the varieties ranged from 2.08-4.85. No chalkiness was recorded in 'Ghansal', 'Kotimirsal' and 'Pusa sugandh-2'. Among the varieties examined $\mathrm{AC}$ was ranged from 17.26-27.69\%. The highest GC was recorded in 'Ghansal' and lowest in 'Pusa Basmati-1'. Kernel length after cooking (KLAC) ranged from 2.31-5.88 mm. Water uptake ratio was ranged from 250-350. Organoleptic-test revealed that the varieties 'Basmati local', 'Jiresal', 'Kotimirsal', 'Pusa Basmati-1', 'Pusa Sugandh-2', 'Pusa Sugandh-3', 'Pusa Sugandh-5', 'Kasturi' and 'Vasumati' were with excellent grain quality characteristics, preference and overall acceptability.
\end{abstract}

Keywords: Basmati rice, Quality, Physicochemical properties, Scented rice

\section{Introduction}

India is one of the largest exporters of basmati rice in the world (Husaini et al., 2009). The consumers demand has increased markedly to pay a premium price for fragrant rice (Louis et al., 2005). Aroma in scented rice depends on the levels of 2-acetyl-1-pyrroline content and it varies with genetic and environmental conditions (Nadaf et al., 2006). Rice is the predominant food crop of Goa occupying an area of 39\% (52 $442 \mathrm{ha}$ ) of the total cultivated land in the state (Manjunath et al., 2009). The kernel appearance, size, shape, aroma, nutritional value and cooking characteristics are important for judging the quality and preference of rice from one group of consumer to another (Dela Cruz and Khush, 2000; Sellappan et al., 2009).

Kernel shape and L/B ratio are important features for grain quality assessment (Rita and Sarawgi, 2008). Aroma, hardness and roughness are depends on temperature and variety specific which affects the sensory properties of cooked rice (Yau and Huang, 1996). Individual preferences varied, most of the consumer's preferred imported rice but differed in their preferences for the local rice (Tomlins et al., 2005).

Study Objectives/purpose

In this paper, we are presenting the finding of grain quality characteristics (physical, chemical, cooking) and organoleptic analysis of traditionally cultivated scented rice varieties of Goa in comparison with basmati rice. 


\section{Materials and methods}

\subsection{Plant material}

The field survey was carried out in different parts of Goa and adjoining regions for the collection of scented rice varieties.

\subsection{Physical traits}

\subsubsection{Hulling percentage}

$100 \mathrm{~g}$ of rice seeds were de-hulled using a standard de-husker and the average whole-grain yield was calculated (Anonymous 2004).

\subsubsection{Grain Classification}

Ten de-husked entire brown rice grains were measured using dial micrometer and based on the L/B ratio, grains were classified into long slender (LS), short slender (SS), medium slender (MS), long bold (LB) and short bold (SB) (Anonymous 2004).

\subsubsection{Chalkiness of endosperm}

Milled rice was observed under a stereo-zoom microscope and based on the orientation of chalkiness, the rice grains were classified into white belly, white centre and white back (Anonymous 2004).

\subsubsection{Chalk index determination}

Ten de-husked rice grains were placed on light box and visually identified the grain with more than $50 \%$ of chalkiness, weighed and percentage of chalkiness was calculated (Anonymous 2004).

\subsection{Chemical traits}

\subsubsection{Alkali spreading value (ASV) and Clearing test}

Six milled rice grains were taken in Petri plates and $10 \mathrm{ml}$ of $1.7 \%$ of $\mathrm{KOH}$ was added and kept in incubator at $27-30{ }^{\circ} \mathrm{C}$ for 23 hours. Then the alkali spreading value was calculated as low, low-intermediate, intermediate or high (Perez and Juliano, 1978).

\subsubsection{Amylose content (AC)}

To $100 \mathrm{mg}$ of rice flour $1 \mathrm{ml}$ of $95 \%$ ethanol and $9 \mathrm{ml}$ of $1.0 \mathrm{~N} \mathrm{NaOH}$ was added. This was mixed well and heated in a boiling water-bath for $10 \mathrm{~min}$. Samples were diluted to $100 \mathrm{ml}$ with distilled water. From this suspension, $5 \mathrm{ml}$ of sample was taken and $1 \mathrm{ml}$ of acetic acid $(57.75 \mathrm{ml}$ in one liter water) was added to acidify the sample along with $1.5 \mathrm{ml}$ of iodine solution ( $0.2 \%$ iodine $+2 \%$ potassium iodide) and the volume was made to $100 \mathrm{ml}$ with distilled water. The samples were incubated at room temperature for $20 \mathrm{~min}$. The absorbance was measured at $620 \mathrm{~nm}$ using spectrophotometer. As a control, $\mathrm{NaOH}$ solution was used. The AC of different varieties was calculated in comparison with standard graph (Perez and Juliano, 1978).

\subsubsection{Gel consistency (GC)}

$100 \mathrm{mg}$ of rice flour was taken in test tube $(2 \times 19.5 \mathrm{~cm}), 0.2 \mathrm{ml}$ of ethanol containing $0.25 \%$ thymol blue and $2.0 \mathrm{ml}$ of $0.2 \mathrm{~N}$ of $\mathrm{KOH}$ were added and kept in boiling water-bath for $8 \mathrm{~min}$, cooled, mixed well and kept in ice bath for $20 \mathrm{~min}$. Later the test tubes were laid horizontally for one hour and measurements were made using graph paper. The degree of disintegration of kernel was evaluated using a 7 point scale (Bhattacharya, 1979).

\subsubsection{Aroma}

To $5 \mathrm{~g}$ of rice $15 \mathrm{ml}$ of water was added, soaked for $10 \mathrm{~min}$ and cooked for $15 \mathrm{~min}$, transferred into a Petri dish and placed in refrigerator for $20 \mathrm{~min}$. Then the cooked rice was smelled by a random panel: strongly scented (SS); mild scented (MS); non scented (NS) (Anonymous, 2004).

\subsection{Cooking characteristics}

\subsubsection{Volume expansion ratio (VER) and elongation ratio (ER)}

$15 \mathrm{ml}$ of water was taken in $50 \mathrm{ml}$ graduated centrifuge tubes and $5 \mathrm{~g}$ of rice sample was added. Initial volume increase was measured $(\mathrm{Y})$ and soaked for $10 \mathrm{~min}$. Then increase in volume before cooking was noted (Y-15). Rice samples were cooked for $20 \mathrm{~min}$ in a water bath. Cooked rice was placed on bloating paper. Ten cooked rice kernels were selected (intact at both ends) and length of the kernels measured using graph paper for computing the kernel length after cooking (KLAC). Then the cooked rice was placed in $50 \mathrm{ml}$ water taken in $100 \mathrm{ml}$ measuring cylinder and increase in volume of cooked rice in $50 \mathrm{ml}$ of water was measured (X). Then the volume raise was recorded (X-50). VER and ER were calculated (Anonymous, 2004). 


\subsubsection{Water Uptake}

$2 \mathrm{~g}$ of samples were taken in graduated test tubes with $10 \mathrm{ml}$ of water and soaked for $30 \mathrm{~min}$. As a control $10 \mathrm{ml}$ of water was taken in 2-3 test tubes. All the test tubes were kept in water-bath for $45 \mathrm{~min}$ at 77 to $80^{\circ} \mathrm{C}$. After cooling, the supernatant of the samples were poured into graduated measuring cylinder and water level was noted. Similarly control water was measured. Then water uptake was calculated as $100 / 2 \mathrm{~g} \times$ actual water absorbed (Anonymous, 2004).

\subsection{Organoleptic test}

To $5 \mathrm{~g}$ of rice samples $15 \mathrm{ml}$ of water were added and soaked for $10 \mathrm{~min}$. Rice samples were cooked in water bath for $15 \mathrm{~min}$ and scored as per panel test performance (Anonymous, 2004).

\subsection{Statistical analysis}

All the experiments were carried out using three replicates. The data were analyzed by using a statistical software WASP-2.0.

\section{Results and discussion}

\subsection{Physical characteristics}

The hulling percentage for traditionally cultivated scented and basmati rice varieties ranged from 72-82 (Table 1). The highest hulling (82.4\%) was noted in variety 'Ek-Kadi' and lowest in 'Basmati local' and 'Kasturi' (72\%), whereas intermediate value was recorded in 'Pusa Sugandh-2' (77.4\%). High hulling percentage resulted in higher head rice yield of $93.3 \%$ in parboiled rice with the higher $(5.5 \times 104 \mathrm{~N} / \mathrm{m} 2)$ process steam pressure (Igbeka et al., 2008). Rita and Sarawgi (2008) reported that the more than 80 value of hulling percentage is preferred and if the hulling percentage increases the head rice recovery also increased. Irregular cracks are caused in rice by hot-air drying but wetting of paddy tended to get healed upon long soaking (Swamy et al., 2009).

Among the varieties studied, the L/B ratio ranged from 2.0-4.8. The variety 'Pusa Basmati-1' recorded the highest $\mathrm{L} / \mathrm{B}$ ratio and least was found in 'Jiresal'. The L/B ratio among basmati varieties ranged from 4.34 to 4.85 , lowest in 'Pusa Sugandh-3'. Based on the L/B ratio, the collected rice varieties were classified into five different categories: 'Basmati local' (long slender), 'Ek-kadi' (long bold), 'Ghansal', 'Jiresal', 'Kotimirsal' (short bold), 'Girga', 'Masuri' (medium slender) and all the basmati rice varieties to the category of extra long slender grains (Table 2). Bhattacharjee and Kulkarni, 2000 analyzed some preferred brands of basmati rice and reported that the $\mathrm{L} / \mathrm{B}$ ratio ranged from $4.47-4.81$.

The chalkiness of the rice grain was classified into white belly, white centre and white back. Among the rice varieties examined, the chalkiness was absent in varieties 'Ghansal', 'Kotimirsal' and 'Pusa Sugandh-2'. The varieties such as 'Basmati local', 'Ek-Kadi' and 'Pusa Sugandh-3' and 'Pusa Sugandh-5', chalkiness were occasionally present whereas in 'Girga', 'Masuri' and 'Pusa Basmati-1' chalkiness were very occasionally present (Table 2). The chalky area more than $20 \%$ was observed in 'Mugada Sugandh' and 'Kasturi'. The percentage of chalkiness in all the varieties studied ranged from 13.8-64.36. The highest chalkiness was recorded in varieties 'Mugadh Sugandh' (31.26) and 'Ek-Kadi' (64.36). 'Basmati local', 'Ek-Kadi', 'Jiresal', 'Pusa Basmati-1', 'Pusa Sugandh-5', 'Mugadh Sugandh', 'Kasturi' and 'Vasumati' have white belly type of chalkiness. White centre was observed in 'Girga', 'Masuri' and 'Pusa Sugandh-3'. The chalky grains reduce the palatability of cooked products, thus the presence of more than $20 \%$ chalkiness in rice kernels is not acceptable in world markets (Cheng et al., 2005).

\subsection{Chemical characters}

The alkali spreading value (ASV) and gelatinization temperature (GT) were calculated for all the rice varieties examined. The low ASV and high GT were detected in 'Basmati local' and 'Mugadh Sugandh'. The intermediate ASV and GT were noted in varieties such as 'Ghansal', 'Girga', 'Jiresal', 'Kotimirsal', 'Pusa Sugandh-2', 'Pusa Sugandh-3' and 'Kasturi'. The high ASV and low GT were recorded in high yielding varieties viz. 'Pusa Basmati-1', 'Pusa Sugandh-5' and 'Vasumati', whereas low-intermediate ASV and high-intermediate GT was observed in traditional scented rice variety 'Ek-Kadi' (Table 3). Cooking time of the rice depends on coarseness of the grain. The intermediate ASV indicated the medium disintegration and classified as intermediate GT which highly desirable for quality grain (Bansal et al., 2006).

The rice varieties were examined for amylose content (AC) and classified as waxy, very low, low, intermediate and high AC. Among the varieties studied, AC ranged from 17.26-27.69\%. The lowest level of AC was recorded in 'Kotimirsal', whereas highest in 'Mugadh Sugandh'. Most of the traditional aromatic varieties showed low 
AC content in comparison with basmati rice varieties (Table 3). Shahidullah et al., 2009 reported that the AC in all grades of rice ranged between 20.7-21.4\%. Cooked rice becomes moist and sticky due to low AC. Amylose and amylopectin in kernels determine the texture of cooked rice and consumers prefer rice with intermediate AC.

The gel consistency (GC) was measured into soft, medium and hard. The GC of the rice samples ranged from $65-70 \mathrm{~mm}$ and categorized as soft, this means the tendency of cooked rice to be soft on cooling. The length of the blue gel was high in aromatic traditionally cultivated rice varieties 'Girga' $20.46 \mathrm{~mm}$ and lowest in 'Kotimirsal' $17.26 \mathrm{~mm}$. In basmati rice 'Mugadh Sugandh' recorded high $27.69 \mathrm{~mm}$ and the lowest in 'Kasturi' $21.83 \mathrm{~mm}$ (Table 3). Amylose content, starch, gel consistency and non-reducing sugar content decrease with elevated temperature (Pandey et al., 2007).

Aroma is an important trait, has high demand in the global market. The native varieties studied during this investigation showed the presence of aroma, for which these varieties are preferred by local people for consumption. Mild aroma was detected in varieties like 'Basmati local', 'Ek-Kadi' and 'Mugadh Sugandh'. 'Ghansal', 'Jiresal', 'Pusa Sugandh-5', 'Kasturi'and 'Vasumati' were more scented than other varieties. The strong aroma was detected in 'Pusa Basmati-1', 'Pusa Sugandh-2' and 'Pusa Sugandh-5' (Table 3). Nadaf et al., 2006 reported that Basmati rice contains more aroma than the traditionally cultivated scented rice varieties.

\subsection{Cooking characteristics}

The volume expansion ratio (VER) in aromatic traditional rice varieties ranged from 2.36-4.10, while in basmati varieties 2.73-3.63. 'Pusa Sugandh-5' showed the VER 3.63 and 'Mugadh Sugandh' with 2.73 (Table 4). It was reported that lower VER is preferred by the consumers than higher VER, on the other hand, higher elongation ratio (ER) of the cooked rice is preferred than lower ER (Shahidullah et al., 2009). Kernel length after cooking (KLAC) ranged from $2.31-3.76 \mathrm{~mm}$ in aromatic traditionally cultivated rice and 4.62-5.88 $\mathrm{mm}$ in basmati rice. Minimum KLAC was observed in 'Kotimirsal' and 'Basmati local'. Kernel elongation ratio (ER) in aromatic traditional rice ranged from 1.01-1.42 and basmati rice ranged from 1.02-1.12. Highest kernel ER was observed in 'Ghansal' and lowest in 'Masuri' (Table 4).

In basmati varieties, water uptake ratio ranged from 280-335 and in aromatic traditional rice varieties 250-350. Among the traditional rice varieties, 'Ek-Kadi' recorded the highest water uptake ratio and minimum in 'Masuri' (Fig.1). The amount of water uptake during cooking process is associated with the appearance of cooked rice (Tan et al., 2000).

\subsection{The Organoleptic Analysis}

The organoleptic-test was conducted for the appearance, cohesiveness, tenderness on touching, tenderness on chewing, taste, aroma, elongation and overall acceptability of cooked rice and evaluated by trained assessors using the above descriptive analysis in a control panels. Sensory specifications are those that can be used to check if a product complies with the stated requirements Costell 2002. The excellent overall acceptability characters were recorded in 'Basmati local', 'Jiresal', 'Kotimirsal', 'Pusa Basmati-1', 'Pusa Sugandh-2', 'Pusa Sugandh-3', 'Pusa Sugandh-5', 'Kasturi' and 'Vasumati'. The good overall acceptability was observed in varieties 'Ek-Kadi', 'Ghansal', 'Girga', 'Masuri' and 'Mugadh Sugandh' (Table 5).

\section{Conclusions}

The paper has concentrated on the physical, chemical, cooking characteristics and organoleptic test with consumer preferences of traditionally cultivated scented and basmati rice varieties. Among the varieties studied traditionally cultivated aromatic rice 'Ek-Kadi' and 'Ghansal' showed maximum hulling percentage. The AC, ASV and GC were excellent in 'Girga', 'Ek-Kadi', 'Mugadh Sugandh', 'Pusa Basmati-1' and 'Pusa Sugandh-3'. The study revealed that the rice varieties viz. 'Basmati local', 'Jiresal', 'Kotimirsal', 'Pusa Basmati-1', 'Pusa Sugandh-2', 'Pusa Sugandh-3', 'Pusa Sugandh-5', 'Kasturi' and 'Vasumati' with best cooking quality characteristics and consumer's preference. Organoleptic analysis always helps the consumers to select better rice varieties for their consumption and use. It is also emphasized that the training and recruiting the sensory expert panel are important in the process of sensory analysis and organoleptic test (Lefebvre et al., 2010). The present study revealed that some of the indigenous aromatic rice varieties have potential for consumer's preferences and it could be used for breeding programmes and biotechnological research for the improvement of valuable grain quality traits.

\section{References}

Anonymous. (2004). Laboratory Manual on Rice Grain Quality Procedure. Directorate of Rice Research, Rajendranagar, Hyderabad, India, pp. 1-20. 
Bansal, U. K, Kaur, H., \& Saini R. G. (2006). Donors for quality characteristics in aromatic rice. Oryza, 43(3):197-202.

Bhattacharjee, P., \& Kulkarni P. R. (2000). A comparative study on the physical characteristics and cooking quality parameters of commercial brands of basmati rice. International Journal of Food Sciences and Nutrition, 51:295-299.

Bhattacharya, K. R. (1979). Gelatinization temperature of rice starch and its determination. In Proceedings of the Workshop on Chemical Aspects of Rice Grain Quality. International Rice Research Institute, pp. 231-249.

Chakravarthi, B. K., \& Naravaneni, R. (2006). SSR marker based DNA finger-printing and diversity study in rice (Oryza sativa L.). African Journal of Biotechnology, 5(9):684-688.

Cheng, F. M., Zhong, L. J., Wang, F., \& Zhang, G. P. (2005). Differences in cooking and eating properties between chalky and translucent parts in rice grains. Food Chemistry, 90:39-46.

Costell, E. (2002). A comparison of sensory methods in quality control. Food Quality and Preference, 13(6):341-353.

Dela Cruz, N., \& Khush, G. S. (2000). Rice grain quality evaluation procedures. In: Aromatic rices. Singh RK, Singh, US, Khush GS, (Eds). Oxford \& IBH Publishing Co. Pvt. Ltd., New Delhi, India, pp. 16-28.

Huang, F. S., Sun, Z. X., Hu, P. S., \& Tang, S. Q. (1998). Present situations and prospects for the research on rice grain quality forming. Chinese Journal of Rice Science, 12(3):172-176.

Husaini, A. M., Parray, G. A., Rather, A. G., \& Sanghera, G. S. (2009). Performance of elite basmati rice varieties of subtropical India under temperate valley conditions of Kashmir, Genetic resources. International Rice Research Notes, 0117-4185.

Igbeka, R. J. C., Gbabo A., \& Dauda S. M. (2008). Effect of variety, pressure and specific volume of steam on the head rice yield of milled parboiled rice. Journal of food science and technology, 45(3):282-283.

Lefebvre, A., Bassereau, J. F., Pense-Lheritier, A. M., Rivere, C., Harris, N., \& Duchamp, R. (2010). Recruitment and training of a sensory expert panel to measure the touch of beverage packages: Issue and methods employed. Food Quality and Preference, 21(1):156-164.

Louis, M. T. B, Robert J. H., Qingsheng, J., Russell, F. R., \& Daniel, L. E. W. (2005). A perfect marker for fragrance genotyping in rice. Molecular Breeding, 16:279-283.

Manjunath, B. L., Prabhudsai, H. T., Wasnik, H. M., Faleiro J. R., Ramesh, R., \& Sunetra, T. (2009). Glimpses of three decades of rice research in Goa. Technical bulletin, 19:1-39.

Pandey, J. P., Archana, \& Singh, G. (2007). Effect of accelerated aging treatments on physico chemical characteristics of 'Basmati' and non-'Basmati' rice. Journal of food science and technology, 44(4):443-445.

Perez, C. M., \& Juliano B. O. (1978). Modification of the simplified amylose test for milled rice. Starch, 30:424-426.

Rita, B., \& Sarawgi, A. K. (2008). Agro-morphological and quality characterization of badshah bhog group from aromatic rice germplasm of Chhattisgarh. Bangladesh Journal of Agriculture Research, 33(3):479-492.

Sellappan, K., Datta, K., Parkhi, V., \& Datta, S. K. (2009). Rice caryopsis structure in relation to distribution of micronutrients (iron, zinc, $\beta$-carotene) of rice cultivars including transgenic indica rice. Plant Science, 177:557-562.

Shahidullah, S. M., Hanafi, M. M., Ashrafuzzaman, M., Ismail, M. R., \& Khair, A. (2009). Genetic diversity in grain quality and nutrition of aromatic rice's. African Journal of Biotechnology. 8(7):1238-1246.

Swamy I. Y. M., \& Bhattacharya, K. R. (2009). Induction and healing of cracks in rice grain during water soaking of paddy. Journal of food science and technology, 46(2):136-138.

Tan, Y. F., Xing, Y. Z., Li, J. X., Yu, S. B., Xu, C. G., \& Zhang, Q. (2000). Genetic bases of appearance quality of rice grains in Shanyou 63 an elite rice hybrid. Theoretical and Applied Genetics, 101:823-829.

Tomlins, K. I., Manful, J. T., Larwer, P., \& Hammond, L. (2005). Urban consumer preferences and sensory evaluation of locally produced and imported rice in West Africa. Food Quality and Preference, 16(1):79-89.

Wakte, V. K., Nadaf, A. B., Krishnan, S., \& Thengane, R. J. (2007). Studies on lower epidermal papillae, the site of storage of basmati rice aroma compounds in Pandanus amaryllifolius Roxb. Current Science, 93:2-25.

Yau, N. J. N., \& Huang, J. J. (1996). Sensory analysis of cooked rice. Food Quality and Preference, 7(3-4):263-270. 
Table 1 . The hulling percentage, $\mathrm{L} / \mathrm{B}$ ratio and grain classification of aromatic traditionally cultivated and basmati rice varieties

\begin{tabular}{|l|l|l|l|l|l|}
\hline Sl. No. & Varieties & $\begin{array}{l}\text { Place of } \\
\text { collection }\end{array}$ & $\begin{array}{l}\text { Mean } \\
\text { Hulling \% }\end{array}$ & $\begin{array}{l}\text { Mean } \\
\text { L/B ratio }\end{array}$ & Grain Classification \\
\hline 1 & Basmati local & Guirim & $72.73 \pm 1.62^{\mathrm{f}}$ & $3.16 \pm 0.04^{\mathrm{f}}$ & Long Slender \\
\hline 2 & Ek-Kadi & Junuswada & $82.46 \pm 1.20^{\mathrm{a}}$ & $2.86 \pm 0.05^{\mathrm{g}}$ & Long Bold \\
\hline 3 & Ghansal & Ajara & $80.96 \pm 1.96^{\mathrm{ab}}$ & $2.16 \pm 0.01^{\mathrm{i}}$ & Short Bold \\
\hline 4 & Girga & Ajara & $79.96 \pm 0.32^{\mathrm{bc}}$ & $2.74 \pm 0.03^{\mathrm{h}}$ & Medium Slender \\
\hline 5 & Jiresal & Borim & $77.73 \pm 2.25^{\mathrm{d}}$ & $2.08 \pm 0.08^{\mathrm{j}}$ & Short Bold \\
\hline 6 & Kotimirsal & Savodam & $77.86 \pm 2.32^{\text {cd }}$ & $2.16 \pm 0.01^{\mathrm{i}}$ & Short Bold \\
\hline 7 & Masuri & Molem & $79.90 \pm 1.60^{\text {bc }}$ & $2.92 \pm 0.02^{\mathrm{g}}$ & Medium Slender \\
\hline 8 & Pusa Basmati-1 & ICAR & $73.40 \pm 0.3^{\mathrm{f}}$ & $4.85 \pm 0.04^{\mathrm{a}}$ & Extra-long slender \\
\hline 9 & Pusa Sugandh-2 & ICAR & $77.46 \pm 0.66^{\mathrm{d}}$ & $4.43 \pm 0.04^{\mathrm{d}}$ & Extra-long slender \\
\hline 10 & Pusa Sugandh-3 & ICAR & $72.50 \pm 0.4^{\mathrm{f}}$ & $4.34 \pm 0.05^{\mathrm{e}}$ & Extra-long slender \\
\hline 11 & Pusa Sugandh-5 & ICAR & $76.46 \pm 0.40^{\text {de }}$ & $4.50 \pm 0.01^{\mathrm{c}}$ & Extra-long slender \\
\hline 12 & Mugadh Sugandh & ICAR & $76.26 \pm 0.11^{\text {de }}$ & $4.77 \pm 0.06^{\mathrm{b}}$ & Extra-long slender \\
\hline 13 & Kasturi & ICAR & $72.46 \pm 0.45^{\mathrm{f}}$ & $4.53 \pm 0.04^{\mathrm{c}}$ & Extra-long slender \\
\hline 14 & Vasumati & ICAR & $74.36 \pm 0.47^{\text {ff }}$ & $4.46 \pm 0.06^{\text {cd }}$ & Extra-long slender \\
\hline
\end{tabular}

Superscript letters $(\mathrm{a}-\mathrm{j})$ indicate significant differences $(p<0.05)$ among different rice varieties. Means with same letter within column are not significantly different $(p<0.05)$, means \pm SD.

Table 2. The chalkiness frequency, kernel area of chalkiness, type and percentage of chalkiness in aromatic rice varieties

\begin{tabular}{|l|l|l|l|l|l|}
\hline $\begin{array}{l}\text { Sl. } \\
\text { No. }\end{array}$ & \multicolumn{1}{|c|}{ Varieties } & Frequency & \multicolumn{1}{|c|}{$\begin{array}{c}\text { Kernel area } \\
\text { (Extent) }\end{array}$} & \multicolumn{1}{|c|}{ Type } & Chalkiness \% \\
\hline 1 & Basmati local & OC & Medium $(11 \%$ to $20 \%)$ & White belly & $34.90 \pm 2.35^{\mathrm{b}}$ \\
\hline 2 & Ek-Kadi & OC & Medium $(11 \%$ to $20 \%)$ & White belly & $64.36 \pm 2.20^{\mathrm{a}}$ \\
\hline 3 & Ghansal & A & None & ND & $0.000 \pm 0^{\mathrm{h}}$ \\
\hline 4 & Girga & VOP & Small (less than $10 \%)$ & White centre & $10.86 \pm 3.09^{\mathrm{g}}$ \\
\hline 5 & Jiresal & OC & Medium $(11 \%$ to $20 \%)$ & White belly & $16.20 \pm 0.9^{\mathrm{f}}$ \\
\hline 6 & Kotimirsal & A & None & ND & $0.000 \pm 0^{\mathrm{h}}$ \\
\hline 7 & Masuri & VOP & Small (less than $10 \%)$ & White centre & $13.83 \pm 1.50^{\mathrm{f}}$ \\
\hline 8 & Pusa Basmati-1 & VOP & Small (less than $10 \%)$ & White belly & $15.30 \pm 0.36^{\mathrm{f}}$ \\
\hline 9 & Pusa Sugandh-2 & A & None & ND & $0.000 \pm 0^{\mathrm{h}}$ \\
\hline 10 & Pusa Sugandh-3 & OC & Medium (11\% to 20\%) & White centre & $27.33 \pm 1.06^{\mathrm{d}}$ \\
\hline 11 & Pusa Sugandh-5 & OC & Medium (11\% to 20\%) & White belly & $24.16 \pm 0.80^{\mathrm{e}}$ \\
\hline 12 & Mugadh Sugandh & P & Long (more than 20\%) & White belly & $31.26 \pm 1.11^{\mathrm{c}}$ \\
\hline 13 & Kasturi & P & Long (more than $20 \%)$ & White belly & $27.30 \pm 1.15^{\mathrm{d}}$ \\
\hline 14 & Vasumati & OC & Medium (11\% to 20\%) & White belly & $14.43 \pm 1.16^{\mathrm{f}}$ \\
\hline
\end{tabular}

Superscript letters $(\mathrm{a}-\mathrm{h})$ indicate significant differences $(p<0.05)$ among different rice varieties. Means with same letter within column are not significantly different $(p<0.05)$, means \pm SD, VOP, very occasionally present; OC, occasionally present; $\mathrm{P}$, present; ND, not detected. 
Table 3. The alkali spreading value (ASV), gelatinization temperature (GT), amylose content (AC), gel consistency $(\mathrm{GC})$ and aroma in aromatic traditionally cultivated and basmati rice varieties

\begin{tabular}{|c|c|c|c|c|c|c|c|}
\hline $\begin{array}{l}\text { Sl. } \\
\text { No }\end{array}$ & varieties & ASV & GT & $\mathrm{AC}$ & $\begin{array}{l}\text { Length of } \\
\text { blue gel }\end{array}$ & GC & Aroma \\
\hline 1 & Basmati local & $\mathrm{L}$ & $\mathrm{H}>74^{\circ} \mathrm{C}$ & $18.31 \pm 0.93^{\text {ef }}$ & $43 \pm 3.60^{c}$ & Medium & $\mathrm{M}$ \\
\hline 2 & Ek-Kadi & LI & HI & $20.36 \pm 0.72^{\text {cd }}$ & $55 \pm 3^{\mathrm{b}}$ & Medium & $\mathrm{M}$ \\
\hline 3 & Ghansal & I & $\mathrm{I}\left(70-74{ }^{\circ} \mathrm{C}\right)$ & $18.7 \pm 1.25^{\text {def }}$ & $63 \pm 3.60^{\mathrm{a}}$ & Medium & $\mathrm{O}$ \\
\hline 4 & Girga & I & $\mathrm{I}\left(70-74^{\circ} \mathrm{C}\right)$ & $20.46 \pm 0.47^{\mathrm{bcd}}$ & $62.3 \pm 2.51^{\mathrm{a}}$ & Soft & OTB \\
\hline 5 & Jiresal & I & I $\left(70-74{ }^{\circ} \mathrm{C}\right)$ & $18.05 \pm 2.20^{\mathrm{ef}}$ & $62.6 \pm 2.51^{\mathrm{a}}$ & Soft & $\mathrm{O}$ \\
\hline 6 & Kotimirsal & I & $\mathrm{I}\left(70-74{ }^{\circ} \mathrm{C}\right)$ & $17.26 \pm 1.05^{\mathrm{f}}$ & $54.6 \pm 2.51^{b}$ & Medium & OTB \\
\hline 7 & Masuri & I & I $\left(70-74{ }^{\circ} \mathrm{C}\right)$ & $19.40 \pm 0.96^{\mathrm{de}}$ & $62.6 \pm 0.57^{\mathrm{a}}$ & Soft & OTB \\
\hline 8 & Pusa Basmati-1 & $\mathrm{H}$ & $\mathrm{L}\left(55-69^{\circ} \mathrm{C}\right)$ & $26.43 \pm 1.68^{\mathrm{a}}$ & $28.0 \pm 1^{\mathrm{e}}$ & Hard & $\mathrm{S}$ \\
\hline 9 & Pusa Sugandh-2 & I & I $\left(70-74{ }^{\circ} \mathrm{C}\right)$ & $25.84 \pm 0.82^{\mathrm{a}}$ & $32.6 \pm 2.08^{\mathrm{de}}$ & Hard & S \\
\hline 10 & Pusa Sugandh-3 & I & $\mathrm{I}\left(70-74{ }^{\circ} \mathrm{C}\right)$ & $26.42 \pm 0.50^{\mathrm{a}}$ & $33.3 \pm 3.51^{\mathrm{de}}$ & Hard & $\mathrm{S}$ \\
\hline 11 & Pusa Sugandh-5 & $\mathrm{H}$ & $\mathrm{L}\left(55-69^{\circ} \mathrm{C}\right)$ & $25.83 \pm 0.33^{\mathrm{a}}$ & $31.0 \pm 1^{\mathrm{de}}$ & Hard & $\mathrm{O}$ \\
\hline 12 & Mugadh Sugandh & $\mathrm{L}$ & $\mathrm{H}>74^{\circ} \mathrm{C}$ & $27.69 \pm 1.48^{\mathrm{a}}$ & $29.3 \pm 2.08^{\mathrm{de}}$ & Hard & M \\
\hline 13 & Kasturi & I & $\mathrm{I}\left(70-74{ }^{\circ} \mathrm{C}\right)$ & $21.83 \pm 0.70^{\mathrm{bc}}$ & $33.6 \pm 5.85^{\mathrm{d}}$ & Hard & $\mathrm{O}$ \\
\hline 14 & Vasumati & $\mathrm{H}$ & $\mathrm{L}\left(55-69^{\circ} \mathrm{C}\right)$ & $22.34 \pm 1.12^{\mathrm{b}}$ & $33.6 \pm 1.52^{\mathrm{d}}$ & Hard & $\mathrm{O}$ \\
\hline
\end{tabular}

Superscript letters (a-f) indicate significant differences $(p<0.05)$ among different rice varieties. Means with same letter within the column are not significantly different $(p<0.05)$, means $\pm \mathrm{SD}$, L, Low; I, Intermediate; LI, Low-intermediate; H, High; HI, High-intermediate; M, mild; O, optimal; S, strong; OTB, other than basmati.

Table 4. The volume expansion ratio, kernel length after cooking, kernel elongation ratio and water uptake in aromatic traditionally cultivated and basmati rice varieties

\begin{tabular}{|l|l|l|l|l|}
\hline $\begin{array}{l}\text { Sl. } \\
\text { No. }\end{array}$ & Varieties & $\begin{array}{l}\text { Volume } \\
\text { Expansion }\end{array}$ & $\begin{array}{l}\text { Kernel length } \\
\text { after cooking }\end{array}$ & $\begin{array}{l}\text { Elongation } \\
\text { ratio }\end{array}$ \\
\hline 1 & Basmati local & $3.63 \pm 0.05^{\mathrm{b}}$ & $3.76 \pm 0.04^{\mathrm{d}}$ & $1.18 \pm 0.04^{\mathrm{b}}$ \\
\hline 2 & Ek-Kadi & $2.36 \pm 0.15^{\mathrm{f}}$ & $3.20 \pm 0.03 \mathrm{~d}^{\mathrm{e}}$ & $1.10 \pm 0.02^{\mathrm{cd}}$ \\
\hline 3 & Ghansal & $3.56 \pm 0.15^{\mathrm{b}}$ & $3.08 \pm 0.08 \mathrm{~d}^{\mathrm{ef}}$ & $1.42 \pm 0.03^{\mathrm{a}}$ \\
\hline 4 & Girga & $4.03 \pm 0.05^{\mathrm{a}}$ & $2.94 \pm 0.04^{\mathrm{ef}}$ & $1.06 \pm 0.04^{\mathrm{def}}$ \\
\hline 5 & Jiresal & $4.10 \pm 0.1^{\mathrm{a}}$ & $2.56 \pm 0.06^{\mathrm{ef}}$ & $1.22 \pm 0.08^{\mathrm{b}}$ \\
\hline 6 & Kotimirsal & $3.56 \pm 0.05^{\mathrm{b}}$ & $2.31 \pm 0.01^{\mathrm{f}}$ & $1.06 \pm 0.01^{\mathrm{def}}$ \\
\hline 7 & Masuri & $4.06 \pm 0.11^{\mathrm{a}}$ & $2.98 \pm 0.01^{\text {ef }}$ & $1.01 \pm 0.04^{\mathrm{g}}$ \\
\hline 8 & Pusa Basmati-1 & $3.06 \pm 0.11^{\mathrm{d}}$ & $5.49 \pm 0.03^{\mathrm{ab}}$ & $1.12 \pm 0.02^{\mathrm{c}}$ \\
\hline 9 & Pusa Sugandh-2 & $3.00 \pm 0^{\mathrm{d}}$ & $4.62 \pm 0.04^{\mathrm{c}}$ & $1.04 \pm 0.01^{\mathrm{efg}}$ \\
\hline 10 & Pusa Sugandh-3 & $3.13 \pm 0.05^{\mathrm{d}}$ & $4.81 \pm 0.01 \mathrm{~b}^{\mathrm{c}}$ & $1.10 \pm 0.01^{\mathrm{cd}}$ \\
\hline 11 & Pusa Sugandh-5 & $3.63 \pm 0.05^{\mathrm{b}}$ & $4.73 \pm 0.05 \mathrm{~b}^{\mathrm{c}}$ & $1.04 \pm 0.01^{\mathrm{efg}}$ \\
\hline 12 & Mugadh Sugandh & $2.73 \pm 0.11^{\mathrm{e}}$ & $4.93 \pm 0.04 \mathrm{~b}^{\mathrm{c}}$ & $1.03 \pm 0.01^{\mathrm{fg}}$ \\
\hline 13 & Kasturi & $3.3 \pm 0.1^{\mathrm{c}}$ & $4.68 \pm 0.03^{\mathrm{c}}$ & $1.02 \pm 0.04^{\mathrm{fg}}$ \\
\hline 14 & Vasumati & $3.6 \pm 0.05^{\mathrm{b}}$ & $5.88 \pm 1.73^{\mathrm{a}}$ & $1.08 \pm 0.01^{\mathrm{cde}}$ \\
\hline
\end{tabular}

Superscript letters $(\mathrm{a}-\mathrm{g})$ indicate significant differences $(p<0.05)$ among different rice varieties. Means with same letter within column are not significantly different $(p<0.05)$, means \pm SD. 
Table 5. Organoleptic analysis of aromatic traditionally cultivated and basmati rice varieties

\begin{tabular}{|c|c|c|c|c|c|c|c|c|c|c|c|c|c|c|c|}
\hline & Characteristics & & ce & Var & ieti & & & & & & & & & & \\
\hline & & 1 & 2 & 3 & 4 & 5 & 6 & 7 & 8 & 9 & 10 & 11 & 12 & 13 & 14 \\
\hline $\mathbf{A}$ & Appearance & & & & & & & & & & & & & & \\
\hline 5 & White & & & & & & & & & & & & & & + \\
\hline 4 & Creamish white/ brown & & + & + & + & + & + & + & & + & + & & + & & \\
\hline 3 & Red streaks & & & & & & & & & & & & & & \\
\hline 2 & White with brown streaks & + & & & & & & & + & & & + & & + & \\
\hline 1 & White with black streaks & & & & & & & & & & & & & & \\
\hline B & Cohesiveness & & & & & & & & & & & & & & \\
\hline 5 & Well separated & & + & + & + & & + & + & + & + & + & + & + & & + \\
\hline 4 & Partially separated & + & & & & + & & & & & & & & + & \\
\hline 3 & Slightly separated & & & & & & & & & & & & & & \\
\hline 2 & Moderately separated & & & & & & & & & & & & & & \\
\hline 1 & Very sticky & & & & & & & & & & & & & & \\
\hline $\mathrm{C}$ & Tenderness on touching & & & & & & & & & & & & & & \\
\hline 5 & Soft & & & & & + & & & & & & & & & \\
\hline 4 & Moderately soft & + & + & & & & & + & + & & & & & + & \\
\hline 3 & Moderately hard & & & & & & & & & + & + & + & & & \\
\hline 2 & Hard & & & + & + & & + & & & & & & + & & + \\
\hline 1 & Very soft & & & & & & & & & & & & & & \\
\hline D & Tenderness on chewing & & & & & & & & & & & & & & \\
\hline 5 & Soft & & + & & & + & & & + & & & & & & \\
\hline 4 & Moderately soft & + & & & & & + & + & & & + & + & & + & \\
\hline 3 & Moderately hard & & & & & & & & & + & & & & & + \\
\hline 2 & Hard & & & + & + & & & & & & & & + & & \\
\hline 1 & Very soft & & & & & & & & & & & & & & \\
\hline $\mathbf{E}$ & Taste & & & & & & & & & & & & & & \\
\hline 4 & Good & + & + & & & + & + & + & & + & + & + & & + & + \\
\hline 3 & Desirable & & & + & + & & & & + & & & & + & & \\
\hline 2 & Tasteless & & & & & & & & & & & & & & \\
\hline 1 & undesirable & & & & & & & & & & & & & & \\
\hline $\mathbf{F}$ & Aroma & & & & & & & & & & & & & & \\
\hline 5 & Strong & & & & & & & & + & + & + & & & & \\
\hline 4 & Optimal & + & & & & & & & & & & + & & + & + \\
\hline 3 & Mild & & + & + & + & + & + & & & & & & + & & \\
\hline 2 & Other than basmati & & & & & & & + & & & & & & & \\
\hline 1 & No scent & & & & & & & & & & & & & & \\
\hline G & Elongation & & & & & & & & & & & & & & \\
\hline 4 & Excellent & & & & & & & & & & & & & & \\
\hline 3 & Good & + & & & + & & & & + & + & + & + & + & + & \\
\hline 2 & Moderate & & + & + & & + & + & + & & & & & & & + \\
\hline 1 & None & & & & & & & & & & & & & & \\
\hline $\mathbf{H}$ & Overall acceptability & & & & & & & & & & & & & & \\
\hline 4 & Excellent & + & & & & + & + & & + & + & + & + & & + & + \\
\hline 3 & Good & & + & + & + & & & + & & & & & + & & \\
\hline 2 & Acceptable & & & & & & & & & & & & & & \\
\hline
\end{tabular}

1-'Basmati local', 2-'Ek-Kadi', 3-'Ghansal'，4-'Girga'，5-'Jiresal'，6-'Kotimirsal', 7-'Masuri', 8-'Pusa Basmati-1', 9-'Pusa Sugandh-2', 10-'Pusa Sugandh-3', 11-'Pusa Sugandh-5', 12-'Mugadh Sugandh', 13-'Kasturi', 14-'Vasumati'. 


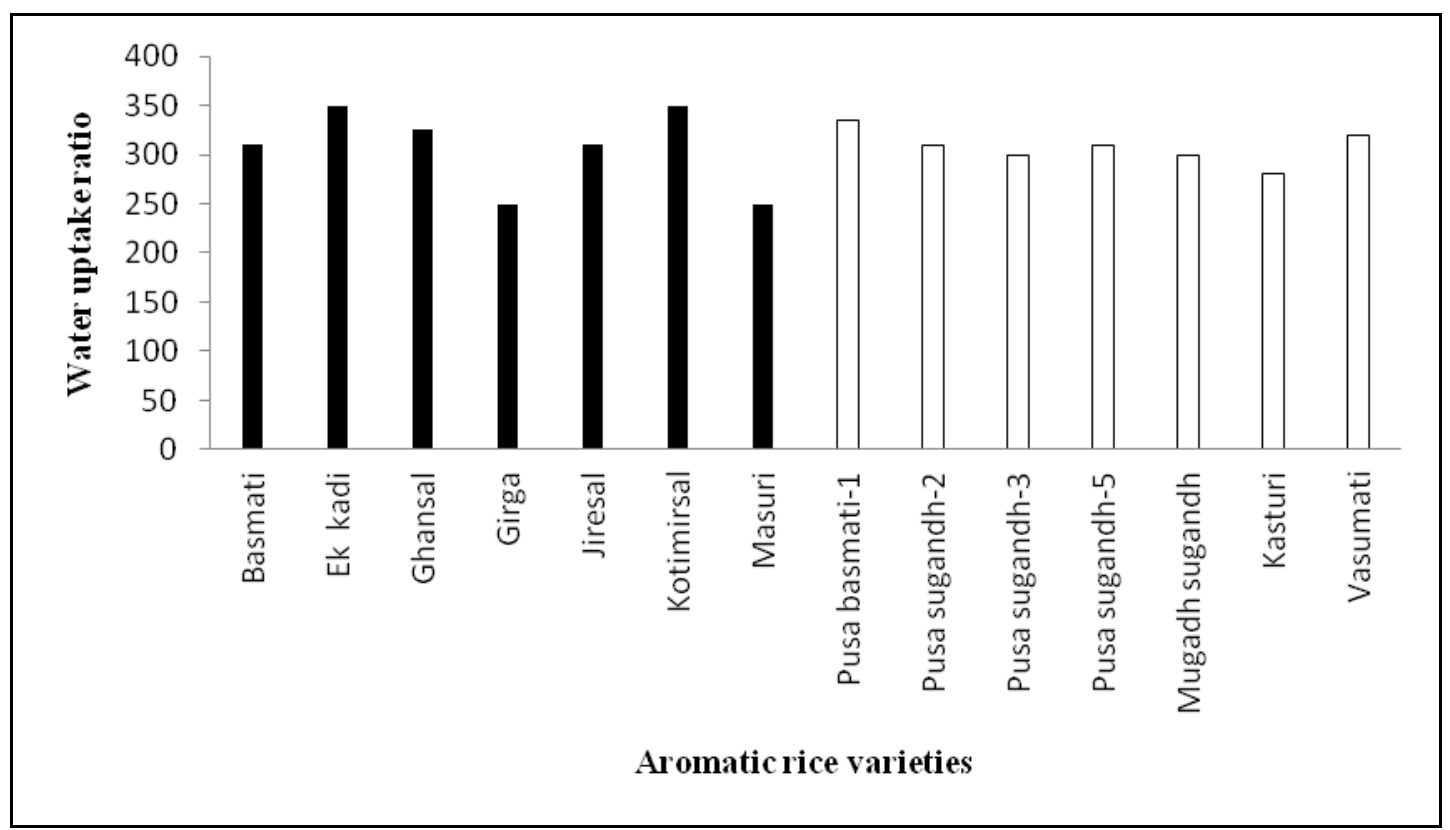

Figure 1. Water uptake in aromatic traditionally cultivated and basmati rice varieties 